\title{
Evapotranspiration and Water Management for Crop Production
}

\author{
André Pereira and Luiz Pires \\ State University of Ponta Grossa \\ Brazil
}

\section{Introduction}

\subsection{Evaporation (E)}

Evaporation is the physical process through which liquid water is converted to water vapor. Water evaporation in the atmosphere is produced by oceans, lakes, rivers, soil, and wet vegetation (evaporation from dew and intercepted rainfall).

\subsection{Transpiration $(\mathrm{T})$}

Transpiration is the loss of water under the form of vapor by the plants, predominantly by means of leaves, although in woody plants a tiny loss might also occur through the lenticels of the bark of branches. On the leaves evaporation befalls from the cell walls into the direction of air intercellular spaces, coming up the diffusion process through the stomata to atmosphere. The stomata acts as a fundamental regulator of transpiration rates along with the adjacent air layer to the leaf. An alternative path to the stomata is the foliar cuticle, although under good water supply conditions the preferential via is the stomachic.

The maintenance of transpiration is achieved by the reposition of lost water, at the vapor phase, by the water from the transpiration current that takes place throughout the conductor system from the roots up to the leaves, as a function of a water potential gradient from the soil $\left(\Psi_{\text {soil }}\right)$ to the air ( $\left.\Psi_{\text {air }}\right)$ as shown in Figure 1 . The atmosphere with its water potential highly negative performs as a drain for water vapor. The drier the air is (low relative humidity), the higher (more negative) the suction force of such a drain will be.

\subsection{Evapotranspiration (ET)}

Evapotranspiration is the simultaneous process of water transfer to the atmosphere both by soil water evaporation and plants transpiration. Depending on the vegetation conditions, size of the vegetated area, and soil water supply, different conceptions are to be defined, such as potential, actual, oasis, and crop evapotranspiration. Such particular terms are described as follows:

\subsubsection{Potential or reference evapotranspiration (ETo)}

Potential evapotranspiration is the amount of water taken up by a large surface vegetated by grass, with a height between 8 and $15 \mathrm{~cm}$, at an active growth stage, covering completely the soil surface, and with no restriction of soil water supply. Conceptually, ETo is limited only by the vertical energy balance, i.e., by the conditions of local ambient. It can be estimated by 
empirical formulae developed and tested for several climatic conditions. Evapotranspiration under such conditions is referred to as reference when the goal is to determine the evapotranspiration of a crop under non standard conditions. Therefore, ETo is an indicative value of the atmospheric demand of a given site throughout a period of time. It is well known that a surface vegetated with grass, under the defined conditions for ETo, has a leaf area index (LAI) of 3 and a reflection coefficient (albedo) for solar radiation corresponding to $23 \%$.

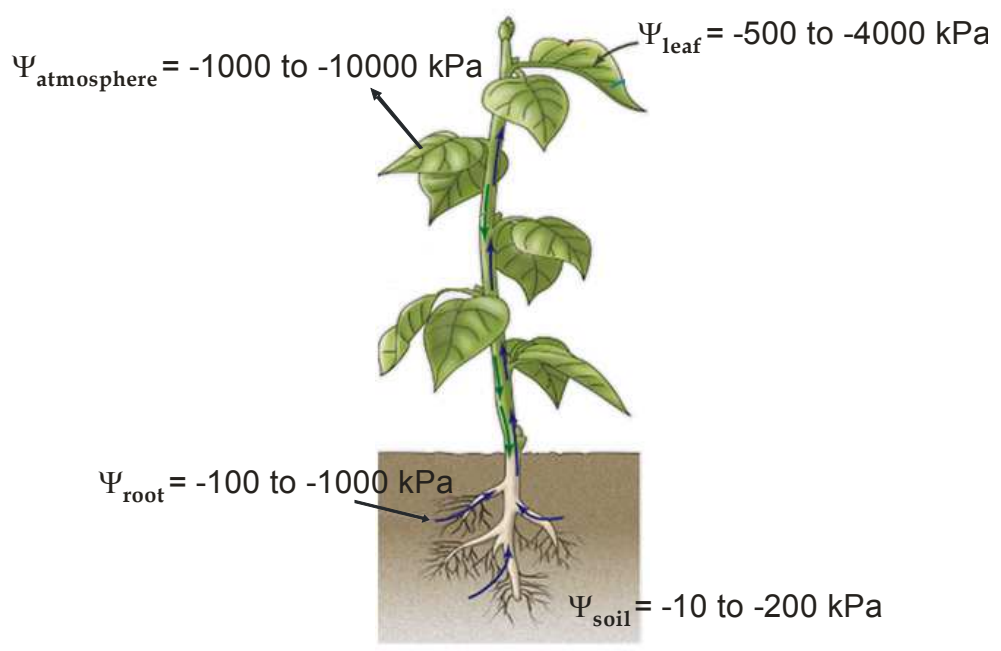

Fig. 1. Schematic representation of the water motion in the soil-plant-atmosphere system under optimal development conditions. Adapted by Reichardt (1985) and http://www.netxplica.com/manual.virtual.

\subsubsection{Actual or real evapotranspiration (ETa)}

Actual evapotranspiration is the amount of water actually utilized by an extensive surface vegetated with grass, at an active growth stage, covering completely the soil surface, however with or without water restriction conditions. Whenever there is not soil water restriction ETa $=$ ETo. Thus, ETa $\leq$ ETo. At this point it is important to emphasize that, by definition, the concepts of ETa and ETo are applicable only to a surface vegetated with grass. Therefore, there is no rational in referring to potential evapotranspiration of a particular crop.

\subsubsection{Oasis evapotranspiration (ETO)}

Oasis evapotranspiration is the amount of water consumed by a small vegetated area (under irrigation) that is surrounded by an extensive dry area at which energy comes from advection (lateral transport of heat by the displacement of air mass), increasing the amount of available energy to evapotranspiration. Thus, by definition, ETO $>$ ETo.

Figure 2 shows the border area necessary for minimizing the lateral transport of energy from the dry to the wet area (irrigated). At such an area, the ET that will take place is the 
oasis evapotranspiration. The size of this area depends on the climate of the region and height of vegetation. Tall vegetations by interacting more efficiently with the atmosphere require a larger border area than that for most grasses. The plants that are closer to the transition line (dry/irrigated) receive an extra amount of energy coming from the dry area, increasing the water consumption of the plants. Plants that are located further the transition spots are less influenced by dry areas and take up less water during the same period. In the case of irrigation, such a management practice should be adopted in such way as to take into account the variation of water loss along the irrigated area. For the central pivot system, the border area is circular. Therefore, the amount of water to be applied has to be calculated adequately in compliance with different demands along the pivot system.

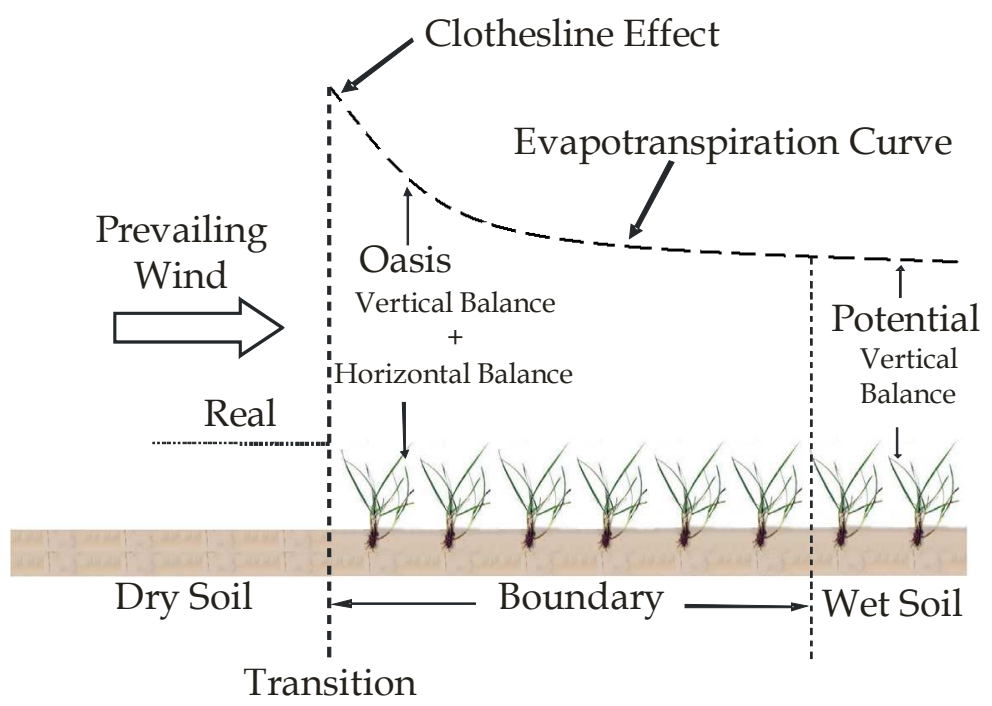

Fig. 2. Schematic representation of the ETO and ETo. Adapted by Camargo \& A.R. Pereira (1990)

\subsubsection{Crop evapotranspiration (ETc)}

Crop evapotranspiration is the amount of water used by a crop at any growth stage, since the sowing / planting date up until the harvest, whenever there is no water restriction in the soil. This process is also called crop maximum evapotranspiration. ETc is a function of leaf area (transpiring surface), because the bigger the leaf area, the higher ETc will be for the same atmospheric demand. ETc might be obtained from ETo by means of the following expression: ETc $=\mathrm{Kc}_{\mathrm{c}}{ }^{*} \mathrm{ETo} . \mathrm{Kc}$ is the crop coefficient and varies with the phenological stage of the crop, and also among species and varieties (cultivars), being a function of LAI. Figure 3 shows the effect of foliar area on water consumption of annual and perennial plants, as well as the variation of Kc throughout the growth/development of such hypothetical crops. In annual crops, in so far as the plant grows the LAI increases until reaching a maximum value, decreasing then afterwards during the period of leaves senescence. Subperiod I depicts the crop establishment (sowing to germination); subperiod II characterizes the vegetative development (germination to flowering); subperiod III represents the reproductive period (flowering to grain filling); and subperiod IV is the harvest. 


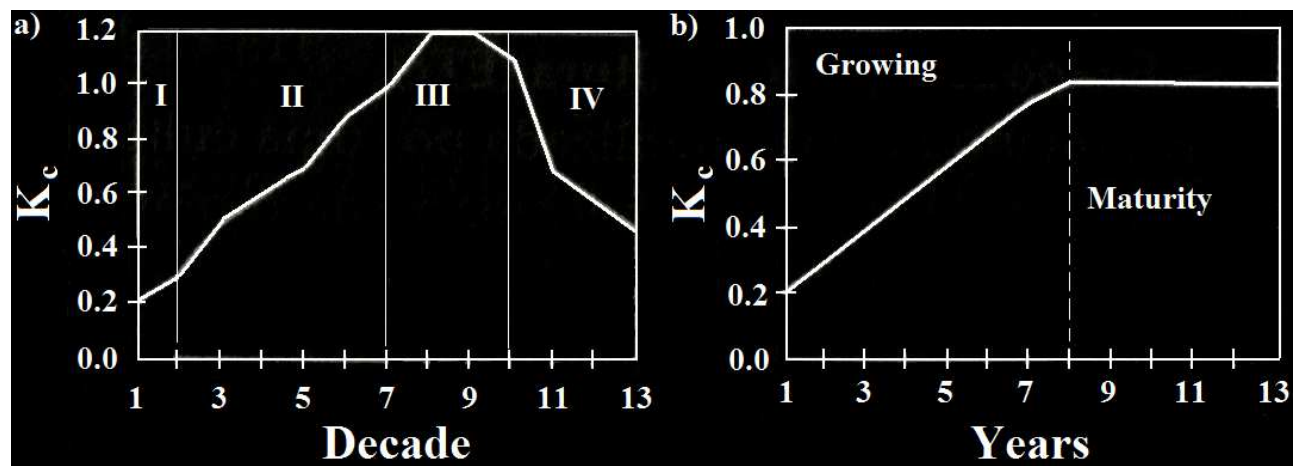

Fig. 3. Relationship between the phenological subperiods and Kc for annual crops, and between age and Kc for perennial crops.

In perennial crops, as a result of a continual growth of the plants, the value of Kc is crescent throughout the years that precede maturity, and from this moment on it turns out to be practically constant with a little seasonal variation, as a function of LAI. One example is the rubber tree, which loses its leaves in fall and also coffee tree that due to harvest and hibernal resting have a reduction in LAI.

When crop evapotranspiration does not occur under the ideal conditions aforementioned, i.e., under water stress condition, ET is denominated crop real evapotranspiration (A.R. Pereira et al., 2002).

\section{Evapotranspiration determining factors}

Weather parameters, crop characteristics, management and environmental aspects are factors affecting evaporation, transpiration, and evapotranspiration.

\subsection{Climatic factors}

\subsubsection{Net radiation}

This is the main source of energy for the evapotranspiration process. It depends on the global solar radiation flux density and vegetation albedo. A darker vegetation absorbs more incident solar radiation and evapotranspires more. Net radiation is the primary climatic factor controlling ET when water is not limiting, especially in subhumid and humid climates. In cold humid climates, only 50 to $60 \%$ of net radiation may be converted to latent heat. In hot, arid climates, latent heat may exceed net radiation by 10 to $50 \%$ with sensible heat derived from the air and converted to latent heat. In spite of these relationships, the heat energy balance approach employed to determining or estimating ET is recognized as a reliable and conservative method. A thorough understanding of the factors controlling the energy balance of a cropped soil enables making accurate estimates or predictions of evapotranspiration and irrigation water requirements. It also facilitates more effective irrigation water management (Allen et al., 1989).

\subsubsection{Temperature}

Over the course of a day, an increase of the air temperature causes an increase on the saturation deficit triggering a higher evaporative demand in the air, and leading to high ET rates. 


\subsubsection{Relative humidity}

Air relative humidity acts in conjunction with temperature. The higher relative humidity, the lesser the evaporative demand and, therefore, the lower ET will be.

\subsubsection{Wind (regional advection of energy)}

Advection represents the horizontal transport of energy from a drier area to another more humid, and such additional energy is utilized in the evapotranspiration process. Wind also helps remove water vapor near the plants to other regions.

\subsection{Crop factors}

\subsubsection{Specie}

This factor is related to the foliar architecture (spatial distribution of the leaves), internal resistance of the plant to water transport, and other morphological aspects (number, size, and distribution of stomata, etc.), which exert a direct influence on ET.

\subsubsection{Reflection coefficient (albedo)}

Radiation reflection influences directly net radiation availability for the ET process. The darker the vegetation, the lower the reflection coefficient and the higher net radiation will be.

\subsubsection{Growth stage (LAI)}

Such a factor is directly related to the size of transpiring foliar surface, for the larger leaf area the larger the transpiring surface, and the higher the potential for water use will be.

\subsubsection{Plant height}

Taller and rougher plants interact more efficiently with the atmosphere in motion, extracting more energy from the air and, therefore, increasing ET.

\subsubsection{Depth of the radicular system}

It is directly related to the volume of soil explored by the roots, aiming at meeting the atmospheric hydric demand. A superficial radicular system, for exploring a smaller soil volume, keeps the crop more susceptible to drying periods.

\subsection{Management and environmental conditions}

\subsubsection{Spacing / stand}

This factor determines the intraspecific competition, i.e., between plants from the same species. Small spacing results in an intensive competition for water and this causes the radicular system to deepen into the soil to enhance the volume of available water. More generous spacing allows for a more superficial radicular system, but also brings about more heating to the soil and plants and promotes a freer circulation of wind among the plants, causing as a consequence an increase on ET.

\subsubsection{Orientation of the crop main line}

Crops oriented perpendicularly to predominant winds tend to extract more energy from the air than those oriented in parallel. For regions with constant winds, a solution to prevent the 
stomata-closing would be the use of windbreaks. A windbreak reduces wind velocities and decreases the ET rate of the field directly beyond the barrier.

\subsubsection{Water storage capacity}

Clay soils have a higher water storage capacity than sandy soils, and are capable of maintaining a more constant ET rate for longer. However, in sandy soils the radicular system tends to be quite deeper, compensating for lower water retention.

\subsubsection{Chemical / physical impediments}

Impediments limit the growth of radicular system, causing the plants to explore a smaller volume of soil, resulting in negative effects both during the rainy and dry seasons. Throughout the rainy season, soil with any physical impediments gets soaking wet asphyxiating the roots. Over the dry season, the volume of available water to the roots turns out to be reduced in such a way as to preclude it from deepening into the soil in search for water.

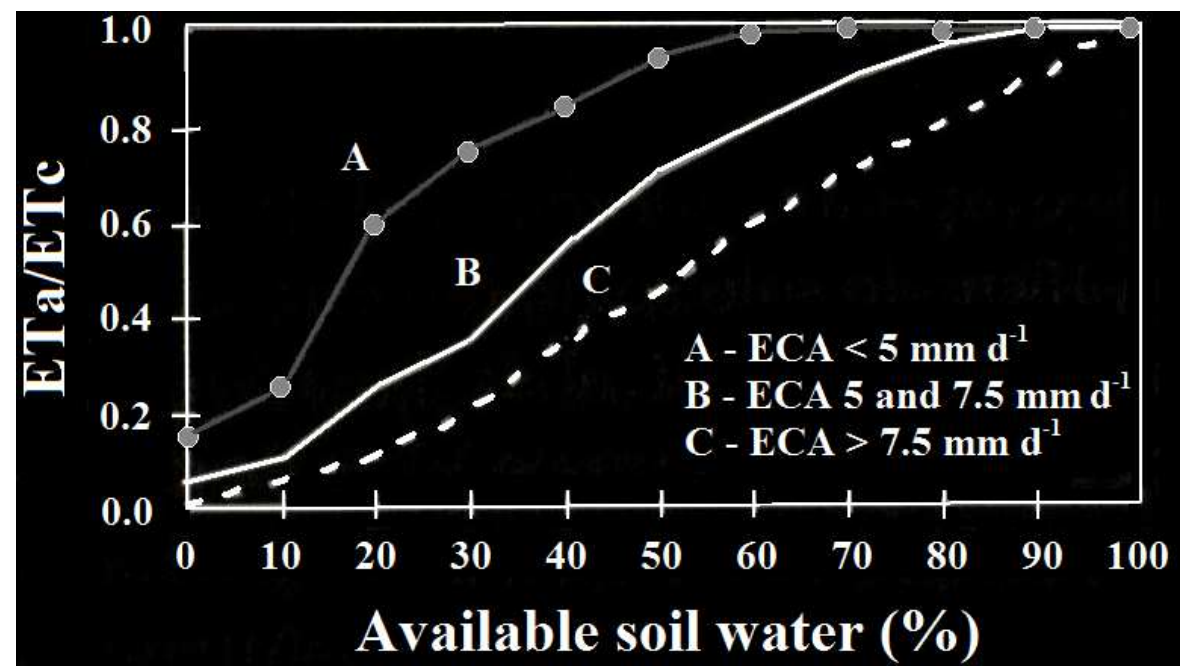

Fig. 4. Interrelationship between corn relative evapotranspiration (ETa/ETc) and soil available water and atmospheric demand expressed by ECA. Adapted by Denmead \& Shaw (1962).

\subsection{Interrelationship atmospheric demand - soil water supply}

The soil is an active reservoir that within certain limits controls the rate of water use by the plants, always in conjunction with the atmospheric demand. The atmospheric demand depends on the availability of solar energy, relative humidity, and wind speed. Figure 4 exemplifies the interrelationship between available water in the soil (\%), atmospheric demand indicated by the evaporation from a Class A pan (ECA), and relative evapotranspiration

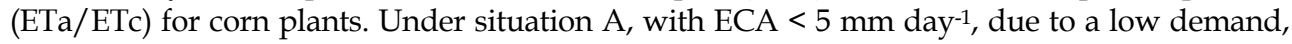
the plant managed to extract water from the soil at potential levels $(\mathrm{ETa} / \mathrm{ETc} \approx 1)$ up to about $60 \%$ soil available water. Under situation C, in which ECA $>7.5 \mathrm{~mm} \mathrm{day}^{-1}$ (high demand), even under enough amount of soil water, the plants do not manage to extract water at a rate 
compatible to its needs, resulting in a temporary enclosure of the stomata to avoid drying of the leaves. Such condition usually takes place at the hottest hours of the day.

\section{Direct measurement of evaporation and evapotranspiration}

Evaporation from an open water surface provides an index of the integrated effect of solar radiation, air temperature, relative humidity and wind speed on evapotranspiration. The Class A pan has proved its practical value and has been used successfully to estimate reference evapotranspiration by observing the evaporation loss from water surface and applying empirical coefficients to relate pan evaporation (ECA) to ETo. Virtually all ET studies are made with supporting climatic data being collected. Pan evaporation is a very common measurement and provides excellent supporting data useful for correlation and prediction. In addition, pan evaporation is commonly measured at reservoir and lake sites to be used in estimating water surface evaporation losses.

Because both pan evaporation and ET involve the same basic process, it is easy to assume that a reasonable estimate of ETo might be found by multiplying measured pan evaporation (ECA) by a factor usually less than unity. The general relationship is:

$$
\mathrm{ETo}=\mathrm{K}_{\mathrm{p}} \text { * ECA }
$$

where $K_{p}$ is known as a pan coefficient which is dimensionless and generally varies from zero to near unity. Doorenbos \& Pruitt (1977) gave pan coefficients to estimate grass reference. Their coefficients are for Class A pan data and consider different ground covers, level of mean relative humidities, and 24-hour wind runs. The coefficients of Doorenbos \& Pruitt (1977) appear in Table 1.

The direct measurement of ET is difficult and expensive, justifying its utilization only under experimental conditions. The equipment more commonly used for such a purpose is the lysimeters. Lysimeter or evapotranspirometer is equipment that consists of an impermeable box containing a soil volume which gives us data concerning the terms of water balance of the sampled soil volume. The most employed lysimeters are:

- Drainage lysimeter: This type of lysimeter works adequately for long periods of observation ( \pm 10 days). It is based on the principle of mass conservation for water in a soil volume (Camargo, 1962):

$$
\Delta \mathrm{SW}=\mathrm{P}+\mathrm{I}-\mathrm{ET}+\mathrm{CR}-\mathrm{DP}
$$

Taking into account that precipitation $(\mathrm{P})$ and irrigation (I) are easily measured, that change in soil water content $(\Delta \mathrm{SW})$ is practically null, that water transported upward by capillary rise (CR) is negligible, and that deep percolation (DP) is measured, we can determine evapotranspiration (ET) as a residue of the above equation.

- Sub-irrigation lysimeter: This kind of lysimeter adopts an automated feeding system and records of reposed water in such a way as to maintain the groundwater at a constant level, being the ET rates equal to the water volume that leaves the feeding system (Assis, 1978).

- Weighting lysimeter: This lysimeter utilizes the automated measurement of load cells set up to an impermeable box, recording its weight variation over time. Hence, faced with water consumption by the plants in the lysimeter a reduction in weight of the control volume will take place and will be proportional to ET (Gomide et al., 1996; Bergamaschi et al., 1997; Silva et al., 1999; Faria et al. 2006). 


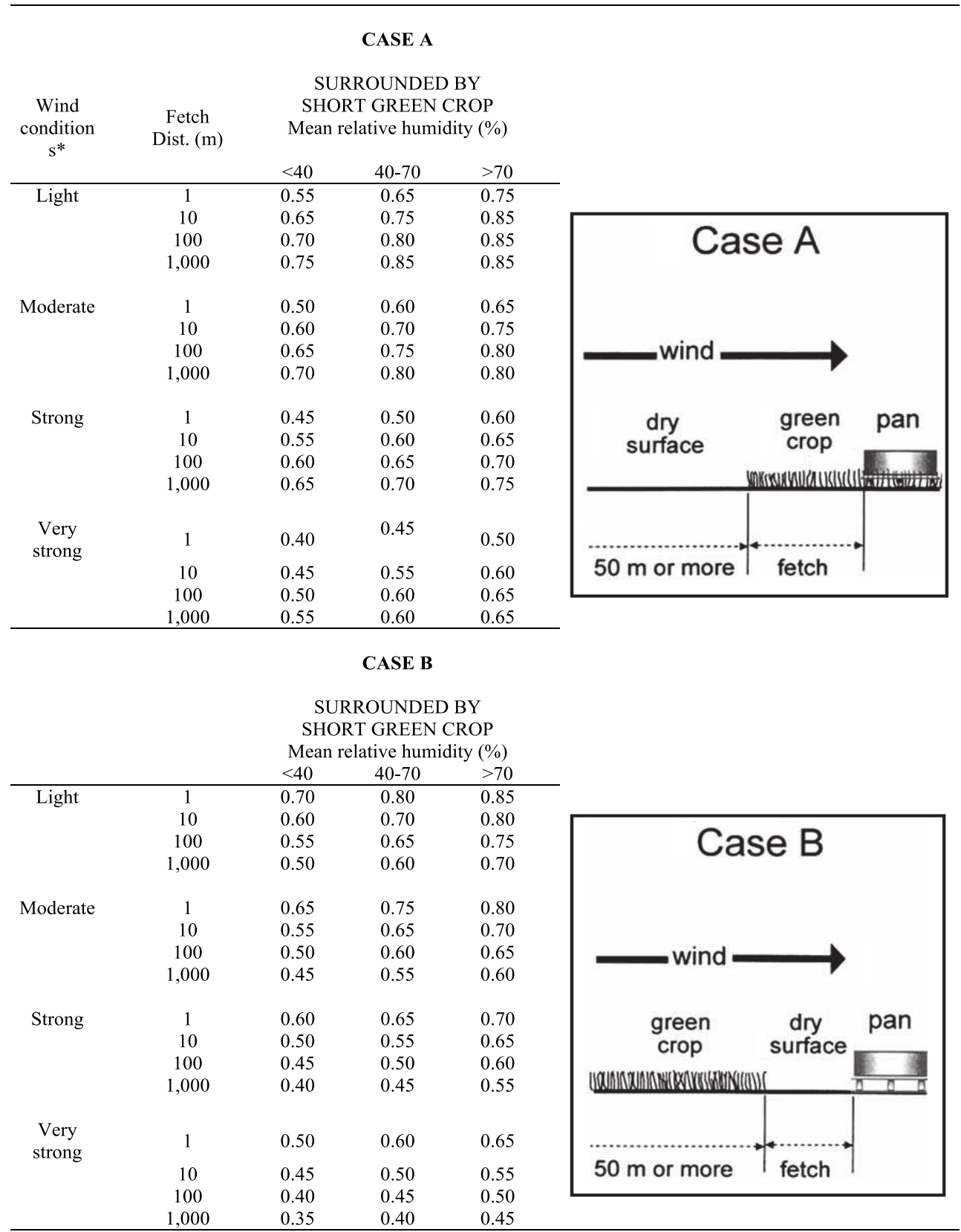

Light: $<175 \mathrm{~km} /$ day, $<2 \mathrm{~m} / \mathrm{s}$; Moderate: $175-425 \mathrm{~km} /$ day, $2-5 \mathrm{~m} / \mathrm{s}$; Strong: $425-700 \mathrm{~km} /$ day, 5-8 m/s; Very strong: $>700 \mathrm{~km} / \mathrm{h},>8 \mathrm{~m} / \mathrm{s}$.

Table 1. Suggested values of Kp for Class A pans for the calculation of ETo for grass 8-15 cm tall. Adapted by Doorenbos \& Pruitt (1977). 


\section{Potential evapotranspiration and crop transpiration estimation methods}

Owing to the difficulty of obtaining accurate field measurements, ETo is commonly computed from weather data. A large number of empirical or semi-empirical equations have been developed for assessing ETo from meteorological information. Some of the methods are only valid under specific climatic and agronomic conditions and cannot be applied under conditions different from those under which they were originally developed.

Numerous methods taking into consideration meteorological data for calculating ETo are reported in the literature. Bernardo (1995) reports that ETo might be obtained by both direct and indirect estimation methods. Direct methods are those that make use of lysimeters and provide the highest accuracy for its determination, require installation of experimental plots in the field, control of soil moisture and a methodological procedure to assess the input and output of water in large areas. However, according to Mendonça et al. (2003), such methods due to its high costs have their use restricted to research institutions and are usually utilized for regional calibration of indirect methods.

ETo needs to be determined to provide knowledge of crop water requirements. It is desirable to have a method that estimates ETo with accuracy and from easily obtained meteorological data. Irrigation planning and decision making at a field scale are done based on calculations of maximum crop evapotranspiration (ETc).

Villa Nova et al. (2007) came up with a simplified method based on the Bowen ratio-energy balance principle to estimate ETo in Brazil. The proposed method is irrespective of monitoring wind speed data and does not require the installation of sophisticated and highcost equipment. In order to get it validated experimental data were collected on a diurnal basis throughout the daylight period, aiming at quantifying only the daylight values of ETo, which are more representative of the water vapor transfer process to the atmosphere for a given agricultural ecosystem. The equation representative of the aforementioned method for ETo expressed in $\mathrm{mm}$ day $^{-1}$ is given by:

$$
\text { ETo }=0.423 * W^{*}(\mathrm{Rn}-\mathrm{G})
$$

where $\mathrm{W}^{\prime}$ is the weighting factor for the effect of solar radiation on evapotranspiration that depends on air temperature, relative humidity, and psychrometric coefficient; $\mathrm{Rn}$ is the net radiation at surface cultivated with grass $\left(\mathrm{MJ} \mathrm{m}^{-2}\right.$ day-1), and $\mathrm{G}$ is the soil heat flux in $\mathrm{MJ} \mathrm{m}^{-2}$ day $^{-1}$. The value for $\mathrm{W}^{\prime}$ can be determined using the data in Tables 2 and 3.

The energy balance method simplified by Villa Nova et al. (2007) was a feasible alternative to evaluate ETo. Under local meteorological conditions of the experiment, it gave estimates practically identical to those obtained by the classical Penman-Monteith approach and added advantage of simplifying ETo calculation, leaving out information related to wind speed, making use of only net radiation, soil heat flux, mean air temperature and mean relative humidity on a daily basis. It showed high statistical accuracy when compared to ETo measurements obtained by weighing lysimeters with load cells.

Another means of calculating ETo based on the Penman approach taking into consideration only the daylight values was suggested by Villa Nova et al. (2006). In their work, the classical expression of the Bowen ratio was modified by considering the sensible heat flux emergent from the evaporative surface in conjunction with the air turbulent flux, which transports also latent heat flux. When compared to potential demand measurements obtained with weighing lysimeters, the simplified Penman approach showed a high statistical accuracy, expressed by coefficients of determination greater than 0.92 , and an 


\begin{tabular}{|c|c|c|c|c|c|c|c|c|c|}
\hline \multirow[t]{3}{*}{$\mathrm{T}\left({ }^{0} \mathrm{C}\right)$} & \multicolumn{9}{|c|}{ Modified weighting factor $\left(W^{\prime}\right)$} \\
\hline & \multicolumn{9}{|c|}{ Relative humidity (\%) } \\
\hline & 45 & 50 & 55 & 60 & 65 & 70 & 75 & 80 & 85 \\
\hline 10 & 0.532 & 0.535 & 0.539 & 0.542 & 0.545 & 0.548 & 0.551 & 0.554 & 0.557 \\
\hline 11 & 0.546 & 0.549 & 0.552 & 0.556 & 0.559 & 0.562 & 0.565 & 0.568 & 0.571 \\
\hline 12 & 0.560 & 0.563 & 0.566 & 0.569 & 0.573 & 0.576 & 0.579 & 0.582 & 0.585 \\
\hline 13 & 0.573 & 0.576 & 0.580 & 0.583 & 0.586 & 0.589 & 0.593 & 0.596 & 0.599 \\
\hline 14 & 0.586 & 0.589 & 0.593 & 0.596 & 0.599 & 0.603 & 0.606 & 0.609 & 0.613 \\
\hline 15 & 0.599 & 0.602 & 0.606 & 0.609 & 0.612 & 0.616 & 0.619 & 0.622 & 0.626 \\
\hline 16 & 0.612 & 0.615 & 0.618 & 0.622 & 0.625 & 0.629 & 0.632 & 0.635 & 0.639 \\
\hline 17 & 0.624 & 0.628 & 0.631 & 0.634 & 0.638 & 0.641 & 0.645 & 0.648 & 0.651 \\
\hline 18 & 0.636 & 0.640 & 0.643 & 0.647 & 0.650 & 0.653 & 0.657 & 0.660 & 0.663 \\
\hline 19 & 0.648 & 0.652 & 0.655 & 0.659 & 0.662 & 0.665 & 0.669 & 0.672 & 0.675 \\
\hline 20 & 0.660 & 0.663 & 0.667 & 0.670 & 0.674 & 0.677 & 0.680 & 0.684 & 0.687 \\
\hline 21 & 0.671 & 0.675 & 0.678 & 0.682 & 0.685 & 0.688 & 0.692 & 0.695 & 0.698 \\
\hline 22 & 0.682 & 0.686 & 0.689 & 0.693 & 0.696 & 0.699 & 0.703 & 0.706 & 0.709 \\
\hline 23 & 0.693 & 0.697 & 0.700 & 0.704 & 0.707 & 0.710 & 0.714 & 0.717 & 0.720 \\
\hline 24 & 0.704 & 0.707 & 0.711 & 0.714 & 0.717 & 0.721 & 0.724 & 0.727 & 0.730 \\
\hline 25 & 0.714 & 0.717 & 0.721 & 0.724 & 0.728 & 0.731 & 0.734 & 0.737 & 0.740 \\
\hline 26 & 0.724 & 0.727 & 0.731 & 0.734 & 0.737 & 0.741 & 0.744 & 0.747 & 0.750 \\
\hline 27 & 0.734 & 0.737 & 0.740 & 0.744 & 0.747 & 0.750 & 0.753 & 0.756 & 0.760 \\
\hline 28 & 0.743 & 0.746 & 0.750 & 0.753 & 0.756 & 0.759 & 0.762 & 0.766 & 0.769 \\
\hline 29 & 0.752 & 0.756 & 0.759 & 0.762 & 0.765 & 0.768 & 0.771 & 0.774 & 0.777 \\
\hline 30 & 0.761 & 0.764 & 0.768 & 0.771 & 0.774 & 0.777 & 0.780 & 0.783 & 0.786 \\
\hline
\end{tabular}

Table 2. Values of the modified weighting factor $\mathrm{W}^{\prime}$ as a function of the observed daily mean air temperature and relative humidity for altitudes from 0 to $1000 \mathrm{~m}$.

\begin{tabular}{|c|c|c|c|c|c|c|c|c|c|}
\hline \multirow[t]{3}{*}{$\mathrm{T}\left({ }^{0} \mathrm{C}\right)$} & \multicolumn{9}{|c|}{ Modified weighting factor $\left(\mathrm{W}^{\prime}\right)$} \\
\hline & \multicolumn{9}{|c|}{ Relative humidity (\%) } \\
\hline & 45 & 50 & 55 & 60 & 65 & 70 & 75 & 80 & 85 \\
\hline 10 & 0.569 & 0.572 & 0.575 & 0.578 & 0.582 & 0.585 & 0.588 & 0.591 & 0.594 \\
\hline 11 & 0.582 & 0.585 & 0.589 & 0.592 & 0.595 & 0.599 & 0.602 & 0.605 & 0.608 \\
\hline 12 & 0.595 & 0.599 & 0.602 & 0.605 & 0.609 & 0.612 & 0.615 & 0.619 & 0.622 \\
\hline 13 & 0.608 & 0.612 & 0.615 & 0.619 & 0.622 & 0.625 & 0.629 & 0.632 & 0.635 \\
\hline 14 & 0.621 & 0.625 & 0.628 & 0.631 & 0.635 & 0.638 & 0.641 & 0.645 & 0.648 \\
\hline 15 & 0.634 & 0.637 & 0.641 & 0.644 & 0.647 & 0.651 & 0.654 & 0.657 & 0.661 \\
\hline 16 & 0.646 & 0.649 & 0.653 & 0.656 & 0.660 & 0.663 & 0.666 & 0.670 & 0.673 \\
\hline 17 & 0.658 & 0.661 & 0.665 & 0.668 & 0.672 & 0.675 & 0.678 & 0.682 & 0.685 \\
\hline 18 & 0.670 & 0.673 & 0.677 & 0.680 & 0.683 & 0.687 & 0.690 & 0.693 & 0.697 \\
\hline 19 & 0.681 & 0.685 & 0.688 & 0.691 & 0.695 & 0.698 & 0.701 & 0.705 & 0.708 \\
\hline 20 & 0.692 & 0.696 & 0.699 & 0.702 & 0.706 & 0.709 & 0.712 & 0.716 & 0.719 \\
\hline 21 & 0.703 & 0.706 & 0.710 & 0.713 & 0.717 & 0.720 & 0.723 & 0.726 & 0.729 \\
\hline 22 & 0.714 & 0.717 & 0.720 & 0.724 & 0.727 & 0.730 & 0.733 & 0.737 & 0.740 \\
\hline 23 & 0.724 & 0.727 & 0.731 & 0.734 & 0.737 & 0.740 & 0.743 & 0.747 & 0.750 \\
\hline 24 & 0.734 & 0.737 & 0.740 & 0.744 & 0.747 & 0.750 & 0.753 & 0.756 & 0.759 \\
\hline 25 & 0.743 & 0.747 & 0.750 & 0.753 & 0.756 & 0.759 & 0.763 & 0.766 & 0.769 \\
\hline 26 & 0.753 & 0.756 & 0.759 & 0.762 & 0.766 & 0.769 & 0.772 & 0.775 & 0.778 \\
\hline
\end{tabular}




$\begin{array}{llllllllll}27 & 0.762 & 0.765 & 0.768 & 0.771 & 0.774 & 0.777 & 0.780 & 0.783 & 0.786 \\ 28 & 0.771 & 0.774 & 0.777 & 0.780 & 0.783 & 0.786 & 0.789 & 0.792 & 0.795 \\ 29 & 0.779 & 0.782 & 0.785 & 0.788 & 0.791 & 0.794 & 0.797 & 0.800 & 0.803 \\ 30 & 0.787 & 0.790 & 0.793 & 0.796 & 0.799 & 0.802 & 0.805 & 0.808 & 0.810\end{array}$

Table 3. Values of the modified weighting factor $\mathrm{W}^{\prime}$ as a function of the observed daily mean air temperature and relative humidity for altitudes from 1000 to $2000 \mathrm{~m}$.

extremely small dispersion of the data around the 1:1 line. Therefore, given the availability of the input data required (net radiation, soil heat flux, and air temperature), it could be employed in other climatic regions besides Brazil to provide ETo estimates for irrigation scheduling.

Solar energy is the primary source for photosynthesis and transpiration in such a way as to assure the expression of the crop potential yield at a given site. A.B. Pereira et al. (2009) came up with a methodology that aims to ease the calculation of the amount of water necessary for a localized irrigation scheduling with a minimal loss possible at both citrus and apple trees orchards by means of usual available data, such as leaf area, global solar radiation flux density, net radiation, and air daily mean steam saturation deficit. In order to get the proposed methodology validated, estimated transpiration data was subjected to a regression analysis against a data set of sap flux measured by means of the heat balance approach in a citrus orchard with leaf areas of 48 and $99 \mathrm{~m}^{2}$, as well as in apple trees with leaf areas roughly of $5,8,9,11,16$ and $21 \mathrm{~m}^{2}$. The calculated transpiration obtained as a function of the conversion efficiency of solar energy for citrus in Brazil is given by the following expression:

$$
\mathrm{TR}=(0.0923-0.0018 * \mathrm{Qg}){ }^{*} \mathrm{LA} * \mathrm{Qg}
$$

where TR is the transpiration rate $\left(1\right.$ tree $^{-1}$ day $\left.^{-1}\right), \mathrm{Qg}$ is the global solar radiation flux density $\left(\mathrm{MJ} \mathrm{m} \mathrm{m}^{-2}\right.$ day $\left.^{-1}\right)$ and LA is the leaf area $\left(\mathrm{m}^{2}\right.$ of leaf tree-1).

The transpiration rate for apple trees obtained by the aforementioned methodology in France is estimated by means of the following equation:

$$
\mathrm{TR}=(0.1+0.0287 * \Delta \mathrm{e}) * \mathrm{Rn} * \mathrm{LA}
$$

where $\Delta \mathrm{e}$ is the mean vapor saturation deficit of the air $(\mathrm{kPa})$ and $\mathrm{Rn}$ is the net radiation $(\mathrm{MJ}$ $\mathrm{m}^{-2}$ day $\left.^{-1}\right)$.

The results obtained by A.B. Pereira et al. (2009) revealed that it is rather feasible to estimate the amount of irrigation water throughout the whole cycle of citrus and apple trees grown under localized irrigation systems by means of a physiological model, which expresses the ability of the plants to converting solar energy into water taken up in the transpiration process at the sites in study.

A.B. Pereira et al. (2010) proposed a new methodology for the calculation of daily transpiration rates of apple trees and citrus orchards from the following meteorological data and crop parameters: mean air relative humidity, mean air temperature, photoperiod duration, and leaf area of the tree. The proposed approach dismisses the utilization of the conductance and net radiation at the dossel level and is the basis for the existing differences between water potential in the atmospheric air and within the stomachic chamber of the leaves. Such a gradient turns out to be the driving-force of the transpiration process. Its utilization as a tool for maximization of yields with a better reclamation of water resources 
under drip irrigation system in orchards was tested as to its viability, taking into account the data of sap flow collected by Angelocci (1996) in apple trees, as well as by Marin (2000) in citrus orchards under distinct climatic conditions.

\section{Crop evapotranspiration and yield response to irrigation}

The determination of a given crop's evapotranspiration (ETc) or water demand is very important for planning water management in irrigated areas, not only from physical and biological points of view, but also from the applied engineering perspective, since the hydraulic design of an irrigation system should take into consideration ET. Work has been performed all over the world to compare values of ETc to those of ETo under different climate and soil conditions. Crop coefficients $(\mathrm{Kc})$ that vary with crop type, canopy cover, and stage of growth have been experimentally calculated (Doorenbos \& Kassam, 1979). Allen et al. (1998) reported extensive tables of Kc for many vegetable crops by species and stage of development.

Irrigation of high-value, water-stress-sensitive crops grown in arid environments is essential for high yield, quality, and net returns. Many of the soils most suited for high-value crops are low in organic matter and are highly susceptible to nutrient and pesticide leaching under poor irrigation scheduling. Improved irrigation and nutrient management practices are important to minimize leaching losses.

The daily ETc of potato varies according to atmospheric conditions, surface soil wetness, the stage of growth, and the amount crop cover (Wright \& Stark, 1990). They observed that ETc increased as the leaf area and transpiration increased and reached near-maximum levels just before effective full cover. The leaf area index reached 3.5 by effective full cover, coincident with the highest daily ETc of $8.5 \mathrm{~mm}$. Seasonal ETc was $604 \mathrm{~mm}$.

Tanner (1981) reported that potato ETc measured with a lysimeter in the humid Wisconsin area for June through August ranged from 293 to $405 \mathrm{~mm}$ during $3 \mathrm{yr}$ of study. Nkemdirim (1976), using meteorological methods, studied the ETc of a potato crop grown near Calgary, $\mathrm{AB}$, Canada, and found midseason daily ETc to be about $6 \mathrm{~mm}$. Daily water consumption for a potato crop grown in Botucatu, São Paulo, Brazil, during the winter season was about 3 $\mathrm{mm}$ and total seasonal ETc was $283 \mathrm{~mm}$ (A.B. Pereira et al., 1995a). Erie et al. (1965) found that the seasonal water use for potato, from February through June at Mesa, AZ, USA, averaged $617 \mathrm{~mm}$.

Wright \& Stark (1990) reported that seasonal water use in irrigated areas of Oregon and Washington ranged from 640 to $700 \mathrm{~mm}$. For high yields at a given site, the seasonal water requirements of a potato crop with a phenological cycle varying from 120 to 150 days were within the range of 500 to $700 \mathrm{~mm}$, depending on the climate (Doorenbos \& Kassam, 1979).

Wright (1982) developed improved crop coefficients for various irrigated crops in the Pacific Northwest, using alfalfa to measure ETo and weighing lysimeters at an experimental field near Kimberly, ID, USA. Apart from the crop coefficient approach, potato ETc can also be estimated by means of multiple regression equations that take into consideration the LAI of the potato crop and atmospheric evaporative demand depicted by ETo or pan evaporation (A.B. Pereira et al., 1995b).

The total water requirement of onion varies considerably with location, environment, and irrigation system. De Santa Olalla et al. (1994) studied onion production with carefully managed drip irrigation and found that bulb yields of 64 to $74 \mathrm{Mg} \mathrm{ha}^{-1}$ were feasible in Spain with water applications of 100 and $120 \%$, respectively, of onion ETc. Bulb yield 
increased with the addition of water up to and above ETc with the soil water tension levels at 20 or $10-\mathrm{kPa}$ (Shock et al., 2000). The total amount of water applied to the $10-\mathrm{kPa}$ treatment $(924 \mathrm{~mm})$ was higher than ETc $(699 \mathrm{~mm})$ and the total amount of water applied to the $20-\mathrm{kPa}$ treatment $(640 \mathrm{~mm})$ was close to ETc. The optimal irrigation treatment, based on economic returns, would be approximately 100\% ETc in 1997 and 153\% ETc in 1998, a rate equivalent to pan evaporation. Bucks et al. (1981) found that the highest irrigation rate tested $(100 \%$ ETc) was advantageous for drip-irrigated onion.

A linear response was found between tomato yield and ETc under surface drip irrigation in Israel (Ben-Gal \& Shani, 2003). The soil texture was sandy loam. The yield-ETc relationship was similar for both spring and fall tomato crops when expressed as relative yield vs. relative ETc. A linear response between yield and ETc also was found for two cultivars at a site in Canada on sandy loam (Tan, 1993). For both studies, deficit irrigation was applied uniformly during the crop season.

Water applications of $0.4,0.6,0.8,1.0$, and 1.2 times the estimated ETc showed processing tomato commercial yield to increase from $9.9 \mathrm{Mg} \mathrm{ha}^{-1}$ (274 mm of water) to $109.6 \mathrm{Mg} \mathrm{ha}-1$ (640 mm of water) with surface drip irrigation on sandy loam on the east side of the San Joaquin Valley (Calado et al., 1990). Deficit irrigation was applied uniformly during the crop season. Soluble solids increased from $4.6 \%$ for the highest water application $(640 \mathrm{~mm}$ of applied water) to $6.5 \%$ for the smallest application ( $274 \mathrm{~mm}$ of applied water). These results suggested that the existing crop coefficients for tomato might underestimate the ETc needed for maximum yield because a higher yield occurred for $1.2 \times$ ETc treatment than the $1.0 \mathrm{x}$ ETc treatment.

Lettuce growth and yield depends on an adequate supply of water to replenish ETc. Gallardo et al. (1996) reported that harvested dry and fresh weight matter of lettuce grown on a sandy loam soil increased linearly as a function cumulative ETc. Yield responses to applied water of amounts equal to 150\% ETc have been reported in sandy textured soils with low water capacities (Sanchez, 2000). Similarly, Bar-Yosef \& Sagiv (1982) obtained highest lettuce yields on a sandy textured soil by applying $120 \%$ of evaporation from a U.S. class A pan.

Water requirements for cabbage vary from 380 to $500 \mathrm{~mm}$ depending on climate and the length of the growing season. The ETc increases during the growing season, with a peak toward the end of the cycle. Pawar \& Firake (2003) studied the effect of three alternate-day irrigation levels (100, 75, and 50\% ETc) and three irrigation methods (drip, drip-line, and microsprinkler) on cabbage yield in a middle block soil at Mahatma, Rahuri, India. They concluded that irrigation scheduled at $100 \%$ ETc produced higher yield (43.4 Mg ha-1) than at $75 \%$ ETc (38.5 $\left.\mathrm{Mg} \mathrm{ha}^{-1}\right)$. The irrigations scheduled at 50\% ETc recorded the lowest yield (30.9 Mg ha-1). Yields were not influenced by the microirrigation methods. Thus, microirrigations for cabbage should be scheduled at the $100 \%$ ETc level to assure maximum yields.

Shock et al. (1998) examined the effect of three deficit irrigation treatments (100\% ETc, 70\% ETc, and 70\% ETc during the bulking with 50\% ETc thereafter) on yield and quality of four potato cultivars in three successive years (1992-1994) on a silt loam soil in eastern Oregon, USA. Yield reductions due to deficit irrigation were not as pronounced in 1993 as in 1992 or 1994. The weather pattern in 1993 was cooler and wetter during the tuber bulking period than it was in either 1992 or 1994. Both total yield and U.S. no.1 yield increased with additional water supply in each of the three years. 


\section{Water use efficiency}

The water use efficiency (WUE) relates the biomass accumulation or commercial yield to the amount of water applied or evapotranspired by the crop (Sousa et al., 2000). In irrigated agriculture the increase of yield and determination of WUE are rather complex and require interdisciplinary knowledge. Within this context, Dinar (1993) mentions the means for enhancing the values of WUE, pointing out the importance of an adequate irrigation scheduling.

Among the means and techniques adopted to increase WUE in irrigated agriculture, drip irrigation with a water supply at a high frequency and low volume has been shown to be adequate for enhancing WUE (Srinivas et al., 1989). Such authors came up with the conclusion that the maximum WUE of a watermelon crop was obtained with drip irrigation systems, whenever water amounts were applied at an evaporation rate of $25 \%$ of class A pan (ECA), owing to the little water stress imposed and a low decrease on yield in comparison to the high reduction in water use. Similar outcomes were also obtained by Lin et al. (1983) by verifying a high WUE under a low irrigation regime for tomato.

When WUE is determined from the amount of water applied, Dinar (1993) and Letey (1993) reported its reduction, however without diminishing crop production as a way of increasing WUE. In such aspect, the irrigation system chosen (Dinar, 1993) and the reduction of the water application period throughout the crop cycle (Richards et al., 1993 e Howell et al., 1998) are important factors to be considered.

The water distribution and maintenance of optimal levels of soil moisture throughout the full cycle of the crop reduce water losses by drainage and water stress period of the crop resulting in increases in WUE. This can be attained with water applications at a high frequency and small amounts (Lin et al, 1983; Srinivas et al., 1989; Mishra et al., 1995; Saeed \& El-Nadi, 1997; Sousa et al., 2000).

Gallardo et al. (1996), working on lettuce yield response to irrigation, reported that WUE was highest for the least irrigated treatment due to more effective extraction of soil water than that of the highest irrigated treatment. Similarly, Aggelides et al. (1999) obtained the highest WUE by reducing the amount of applied water on a clay loam soil. Sammis et al. (1988) describe a linear relationship between lettuce yield and applied water until maximum yield was attained on a silt loam soil in Hawaii, USA. Their model predicted similar WUE for varying amounts of applied water until maximum yield was attained, after which WUE decreased.

WUE for lettuce can also differ among irrigation methods. The use of drip irrigation can reduce evaporation from the soil surface compared to sprinkler and furrow irrigation systems. Hanson et al. (1997) found a higher WUE for drip than furrow in an unreplicated trial. Sutton \& Merit (1993) calculated that drip increased WUE more than 100\% compared to overhead sprinklers. However, Sammis (1980), in comparing drip, sprinkler, and furrow, reported that WUE was not significantly different among the irrigation methods when similar amounts of water were applied, except for furrow which had the highest WUE during the second season and the lowest WUE during the third season. Sammis (1980) as well as Hanson et al. (1997) noted that management was an important factor in the WUE of each irrigation method.

\section{Crop potential productivity modeling}

Potential productivity is the maximum possible yield of a given species or cultivar achievable under the existing conditions of solar radiation flux density with all the other 
environmental factors considered to be optimal. Therefore, the potential productivity is determined by the biological properties of the cultivar and the solar radiation resources available under ETc conditions. The potential yield of agronomic crops is dramatically affected by the amount of water applied during the crop-growing season at a given region.

Meteorological factors directly influence potential crop productivity, regulating its transpiration, photosynthesis, and respiration processes in such a way as to control the growth and development of the plants throughout their physiological mechanisms at a given site. The interaction of the meteorological factors with the crop responses is complex. However, by assessing physiological crop responses to environmental factors under field conditions, it is possible to derive mathematical models to estimate crop potential production as a function of climatic variables with good precision.

Research has been conducted to quantify the effects of the environment on growth, development, and yield of many agronomic crops. Among the main environmental factors that strongly govern all physiological processes of the plants are global solar radiation flux density, air temperature, and available soil water content (Coelho \& Dale, 1980). Currently there is a great deal of interest in estimating crop productivity as a function of climatic factors by means of different crop weather models.

Kadaja \& Tooming (2004) proposed a relatively simple model, POMOD, to calculate potato potential yield, which permits integration of the knowledge in different disciplines on the potato crop yield levels using the measured physiological, ecological, agrometeorological, and agronomical parameters of the plant. The input variables of the model can be divided into four groups: daily meteorological information, annual information, location, and cultivar. The first group includes global solar radiation, air temperature, and precipitation. The location is characterized by geographical latitude and hydrological parameters. As to cultivar, the parameters of gross and net photosynthesis, the coefficients of growth and maintenance respiration, and albedo of the crop are also needed.

The potato growth models included in DSSAT (Decision Support System for Agrotechnology Transfer) are SUBSTOR-POTATO and LINTUL-POTATO (University of Hawaii, Honolulu, Hawaii).

The SUBSTOR-POTATO crop soil weather model takes into consideration daily air temperature, photoperiod duration, intercepted solar radiation, soil water, and nitrogen supply. The model simulated fresh tuber yields ranging from 4 to $56 \mathrm{t} \mathrm{ha}^{-1}$ resulting from differences in weather patterns, soils, cultivars, and management practices (Bowen, 2003).

The LINTUL-POTATO simulation model (Kooman \& Haverkort, 1995) establishes potential yield of a certain cultivar for a determining growing period and plant density and is based on incident photosynthetically active radiation (PAR), the fraction of PAR intercepted by the crop, and radiation use efficiency to produce dry matter. The potential yield established with this model was used by Caldiz \& Struit (1999) to perform a preliminary yield gap analysis regarding actual and attainable potato yield in different areas of Argentina, and provided estimates ranging from 47 to $126 \mathrm{t} \mathrm{ha}^{-1}$. Differences between actual and potential yield might be attributed to suboptimal solar radiation intercepted by the foliage, cultivar, seed management, physiological age of the seed, suboptimal management of water and fertilizer, and inadequate control measures for diseases.

A.B. Pereira \& Villa Nova (2008) tested the performance of a model based on studies of maximum rates of carbon dioxide assimilation for a $C_{3}$ crop as a function of air temperature, fraction of PAR intercepted by the crop, photoperiod duration, and leaf area index to estimate the potential productivity of potato in Brazil. To assess the performance of the 
proposed model, the estimated values of tuber yield were compared with observed productivity data under irrigation conditions for the studied sites. Such agrometeorological model was similar to the potential productivity estimation model described by Villa Nova et al. (2001) and used by Villa Nova et al. (2005) for sugar cane in Piracicaba, State of São Paulo, Brazil. The results obtained by A.B. Pereira \& Villa Nova (2008) showed that the agrometeorological model tested under the climatic conditions of the State of São Paulo, Brazil, in general underestimated irrigated potato yield by less than $10 \%$. This justifies the recommendation to test the performance of the model in other regions for different crops and genotypes under optimal irrigation conditions in further scientific investigations.

Todorovic et al. (2009) compared the performance of AquaCrop, a crop simulation model developed by FAO, with that of two well established models CropSyst and WOFOST, in simulating sunflower growth under different water regimes in a Mediterranean environment. The models differ in the level of complexity describing crop development, in the main growth modules driving the simulation of biomass growth, and the number of input parameters. AquaCrop is exclusively based on the water-driven module, in that transpiration is converted into biomass through a water productivity parameter; CropSyst is based on both water and radiation driven modules, while WOFOST simulates crop growth using a carbon driven approach and fraction of intercepted radiation. All three models tested in this work simulated fairly well most of the situations encountered in the experimental works on sunflower growth in Southern Italy. In most of the simulation scenarios, yield was modeled with a reasonable error of $\pm 0.5 \mathrm{Mg} \mathrm{ha}^{-1}$. A general trend of underestimation of yield by all models was observed under severe water stress conditions.

The AquaCrop model introduces notable simplifications and requires fewer input parameters than the other two models, without affecting negatively its performances in terms of final biomass, yield, and WUE, except that CropSyst simulated WUE much better under limited water supply. However, the simplifications adopted in AquaCrop and also in CropSyst could be a limiting factor of both models when severe water stress conditions need be analyzed. The crop parameters calibrated for all three models under full irrigation in 2007 were shown to be mostly conservative enough to be used in all other simulations regardless of the water regimes and weather and soil characteristics variations in 2 yr under study. However, the predictions of biomass growth during the season were slightly better for 2007 (year of calibration) than for 2005. This means that slight modifications of crop growth parameters for 2005 could improve the simulation results by all models. This is particularly true for CropSyst and WOFOST since both models use crop growth modules that could be affected by weather characteristics (VPD and air temperature, respectively). Furthermore, it should be emphasized that the results obtained in this work depend on the calibration procedure, and for subsequent calibration/validation studies of the model(s), a parameter estimation algorithm with a well-defined goodness of fit criterion should be implemented. Moreover, for more robust model calibrations, it is usually necessary to have much more than $2 \mathrm{yr}$ of experimental work under different weather and soil conditions. Also, a variation in crop growth parameters among different cultivars should be explored. Therefore, further investigations are needed to improve the model performances in predicting sunflower growth in the Mediterranean region.

There is room for improvement of simulations by all these models through more detailed measurement and elaboration of experimental data, and this could be particularly true for the WOFOST model that uses different sets of crop growth parameters as a function of 
development stage. Accordingly, the simulation of biomass growth during the crop time course is better by WOFOST than by the other two models. However, these more detailed input parameters connote a more complex and time consuming calibration procedure that, in some cases, could be an impediment for its extensive use. Therefore, for management purposes and in the conditions of limiting input information, the use of simpler models, such as AquaCrop, should be encouraged.

According to Steduto (2009), the aim of FAO is to have a functional canopy-level waterdriven crop simulation model of yield response to water that can be used in the diverse agricultural systems that exist worldwide. It is therefore imperative that model calibration and validation, specific for each crop, are performed as extensively as possible. The current version of AquaCrop simulates several main crops (Hsiao et al., 2009 and Heng et al., 2009 for maize; García-Vila et al., 2009 and Farahani et al., 2009 for cotton; Geerts et al., 2009 for quinoa). Additionally, wheat is being calibrated with data from several locations around the world. The network of partners in this endeavor is growing and contributing to either further testing of the model calibrated already for specific crops or to parameterize and calibrate the model for additional crops (e.g., forages, oil and protein crops, tuber and root crops, and few major underutilized crops). Relative to other simulation models, AquaCrop requires a low number of parameters and input data to simulate the yield response to water, hopefully for most of the major field and vegetable crops cultivated worldwide. Its parameters are explicit and mostly intuitive, and the model has been built to maintain an adequate balance between accuracy, simplicity, and robustness. The model is aimed at a broad range of users, from engineers, economists, and extension specialists to water managers at the farm, district, and higher levels. It can be used as a planning tool or to assist in making management decisions, whether strategic, tactical or operational. AquaCrop incorporates current knowledge of crop physiological responses into a tool that can predict the attainable yield of a crop based on the water supply available.

\section{Future challenges for crop production: Irrigation systems}

Drip irrigation has not become a standard practice for potato production. Drip irrigation can precisely apply water and chemicals to crops at low pressure and, thus, has the potential to save water, energy, and chemicals; however, the high installation costs combined with the lack of better understanding about drip tape placement, flow rates, and efficacy of chemicals delivered through drip systems in different soil types raise growers' concern about shifting their potato production systems to drip irrigation. Chemicals applied through a drip irrigation system could influence residue levels in the tubers or affect breakdown and movement.

Limited success was associated with deep drip tube placement (Neibling \& Brooks, 1995; DeTar et al., 1996). Deep drip tape placement lowered yield and grade due to poorer water supply to the shallow root system. Shallow drip tape placement in heavy-textured soils saved water, but reduced tuber quality because of soil saturation and subsequent soil adherence on the tubers.

Drip irrigation can deliver chemicals in small doses directly to the root system of the crop; chemical use could be reduced. Irrigation scheduling and pesticide timing for more effective nematode control and control of the potato early die syndrome have the potential to increase potato yield and quality, offsetting drip system costs. 
If it is possible to use drip irrigation to reduce the relative humidity of the air in potato production systems, potato late blight pressure should be reduced. Entire fields or at least the center of the filed could be converted to drip irrigation to eliminate unfavorable microclimatic conditions favoring, therefore, the development and spread of potato foliar diseases promoted by a center pivot. Fungicidal sprays might not be needed most years to control late blight where such a disease often occurs.

Changing the canopy environment to reduce duration of leaf wetness may protect the plants from pests that reduce potato yield and grade at a given site. One approach is to orient potato rows parallel to the prevailing direction of the wind (Powelson et al., 1993). Planting cultivars that do not produce extensive vines or even cultivars that have an upright growth habit may be of value in regions with a history of severe disease occurrences. An alternative is to stop irrigation in early afternoon to allow plants to dry before evening (Powelson et al., 1993). Spread of US-1 and US-8 isolates of Phytophthora infestans in field plots of Russet Burbank grown in Pullman, WA, USA, was favored by sprinkler irrigation during evening hours (Miller \& Johnson, 2000).

Optimizing onion yields with furrow irrigation can be difficult because of low application efficiency and low distribution uniformity. Furrow irrigation can also result in excessive erosion and NO3 leaching. Different irrigation systems have been compared for onion production. Ellis et al. (1986) did not find significant differences in onion yields between sprinkler and drip irrigation systems on heavy-textured soils in Colorado, USA. When growing onion on silt loam soils in southeastern Oregon, Feibert et al. (1995) found advantages for drip and sprinkler irrigation on sites that were difficult to irrigate with furrow irrigation. Al-Jamal et al. (2000) achieved higher yields using drip than sprinkler irrigation.

Since onion has little crop canopy and a weak root system, furrow irrigation on sloping ground can lead to substantial soil and nutrient losses in runoff water (Shock et al., 1997). Mechanically applied wheat straw at $900 \mathrm{~kg}$ ha-1 substantially reduced sediment and nutrient losses from furrow-irrigated onion (Shock \& Shock, 1998). The straw was divided into two applications to permit cultivation, $45 \%$ before the first irrigation and the remainder after the last cultivation. Straw increased onion bulb yield in replicated plots and growers fields, probably due to decreased soil water tension (Shock et al., 1999).

Statistically similar processing tomato yields were found for surface drip irrigation and furrow irrigation on loam soil at the University of California, Davis, although higher average yields occurred for the drip system compared with the furrow system (Pruitt et al., 1984). Similar ETc occurred for both irrigation methods. Lysimeter data showed furrow ETc to exceed drip ETc during irrigation, but shortly after furrow irrigation, drip ETc exceeded furrow ETc.

Furrow, sprinkler, and surface and drip irrigation of processing tomato were compared on a sandy loam for 2 years in southeast Spain (Prieto et al., 1999). Yield differences between irrigation methods were insignificant for the first year, although the highest yield occurred for sprinkler irrigation and the lowest for furrow irrigation. In the second year, the highest yield occurred for drip irrigation (statistically significant), while yields of sprinkler and furrow irrigation were similar.

Sprinkler irrigation, drip irrigation, and an unirrigated treatment were compared at a site in southwest Ontario, Canada (Tan, 1995). The soil type was sandy loam. Results were complicated by varying amounts of rainfall for each of the 4 years of experiment. Higher tomato yield occurred for drip irrigation for 2 years compared with the other irrigation 
treatments, while the yield of sprinkler irrigation or unirrigated treatment was higher for the other 2 years. A significant cultivar effect on yield occurred.

Several comparisons have been made among furrow, sprinkler and drip for lettuce. Sammis (1980) found that yields under furrow were comparable or higher than yields under surface and subsurface drip during the first 2 years of a 3-year field study. Flooding during stand establishment caused the furrow treatment to be the lowest yielding during the third year of the trial. Yields under sprinklers were significantly lower than the drip treatments during the first 2 years of the trial. In comparing furrow with surface and subsurface drip in large, unreplicated plots over three crop cycles, Hanson et al. (1997) reported highest yields in the furrow treatment, which received 1.3 to 2.3 times the amount of water applied by drip. Fresh weight of lettuce plants was more variable in the furrow than in the drip plots. Plant density was similar under all irrigation methods. Nitrogen content of the leaves was similar among irrigation methods for the second crop, but highest in the furrow plot of the third crop.

Sharanappa-Jangandi et al. (2001) investigated the effect of drip irrigation frequency (daily, alternate days, or every third, fourth, or fifth day) on cabbage yield in a medium black soil at Hiriyur, Karnataka, India, and compared it with irrigation every fourth day using a furrow system. Daily drip irrigation resulted in the highest yield $\left(69.0 \mathrm{Mg} \mathrm{ha}^{-1}\right)$ and WUE of $54.2 \mathrm{~g} \mathrm{~L}^{-1}$. Drip irrigation on alternate days resulted in good yields of $65.6 \mathrm{Mg} \mathrm{ha}^{-1}$ and WUE of $51.5 \mathrm{~g} \mathrm{~L}^{-1}$. Irrigation using a furrow system produced $29.6 \mathrm{Mg} \mathrm{ha}^{-1}$. The yield response to irrigation was found to be 2 or 4 times higher with drip irrigation than with furrow irrigation. Drip irrigation treatments used 1.27 ML ha-1 of water in comparison with $4.80 \mathrm{ML}$ ha $^{-1}$ for the furrow system.

\section{Acknowledgments}

Many thanks are owned to the Brazilian Federal Funding Agency, Conselho Nacional de Desenvolvimento Científico e Tecnológico - $\mathrm{CNPq}$ - for the provision of the productivity scholarship, as well as to Sandy Shelton MSc., from San Francisco, CA, USA, for the thorough revision on the English of the current book chapter.

\section{References}

Aggelides, S., Assimakopoulos, I., Kerkides, P. \& Skondras, A. 1999. Effects of soil water potential on the nitrate content and yield of lettuce. Commun. Soil Sci. Plant Anal. 30:235-243.

Al-Jamal, M.S., Sammis, T.W., Ball, S. \& Smeal, D. 2000. Computing the crop water production function for onions. Agric. Water Manage. 46:29-41.

Allen, R.G., Jensen, M.E., Wright, J.L. \& Burman, R.G. 1989. Operational estimates of evapotranspiration. Agronomy Journal 81:650-662.

Allen, R.G., Pereira, L.S., Raes, D. \& Smith, M. 1998. Crop evapotranspiration: Guidelines for computing crop water requirements. Rome: FAO. (Irrigation and Drainage Paper, 56).

Angelocci, L.R. 1996. Estimativa da transpiração máxima de macieiras (Malus spp) em pomares pelo método de Penman-Montheith. Tese (Livre-Docência) - Escola Superior de Agricultura “Luiz de Queiroz", Universidade de São Paulo. 95p. 
Bar-Yosef, B. \& Sagiv, B. 1982. Trickle irrigation and fertilization of iceberg lettuce Lactuca sativa. p.33-38. In: A. Scaife (ed.) Plant nutrition 1982: Proc. Int. Plant Nutr. Colloqu., 9th, Conventry, UK. 22-27 Aug. 1982. Commonw. Agric. Bur., Slough, UK.

Ben-Gal, A. \& Shani, U. 2003. Water use and yield of tomatoes under limited water and excess boron. Plant Soil 256:170-186.

Bergamaschi, H., Santos, M.L.V., Medeiros, S.L.P. \& Cunha, G.R. Automação de um lisímetro de pesagem através de estação meteorológica a campo. In: Congresso Brasileiro de Agrometeorologia, 10, Piracicaba, 1997, p.176-177.

Bernardo, S. 1995. Manual de irrigação. 6a edição. Viçosa, Universidade Federal de Viçosa. $657 \mathrm{p}$.

Bowen, W.T. 2003. Water productivity and potato cultivation. p.229-238. In: Kijne, J.W., R. Barker \& D. Molden (eds.). Water productivity in agriculture: Limits and opportunities for improvement. CAB International Sri Lanka. Accessed on27 Nov. 2005.http://www.iwmi.cgiar.org/pubs/Book/CA_CABI_Series/Water_Productivi ty/Protected/0851996698ch14.pdf.

Bucks, D.A., Erie, L.J., French, O.F., Nakayama, F.S. \& Pew, W.D. 1981. Subsurface trickle irrigation management with multiple cropping. Transaction of ASAE 1981:1482-1489.

Calado, A.M., Monzon, A., Clark, D.A., Phene, C.J., Ma, C. \& Wang, Y. 1990. Monitoring and control of plant water stress in processing tomato. Acta Horticulture 277:129-136.

Caldiz, D.O. \& Struit, P.C. 1999. Survey of potato production and possible yield constraints in Argentina. Potato Research 42:51-71.

Camargo, A.P. \& Pereira, A.R. 1990. Prescrição de rega por método climatológico. Campinas, Fundação Cargill. 27p.

Coelho, D.T. \& Dale, R.F. 1980. An energy-crop growth variable and temperature function for predicting corn growth and development. Planting to silking. Agronomy Journal 72:503-510.

Denmead, O.T. \& Shaw, R.H. 1962. Availability of soil water to plants as affected by soil moisture content and meteorological conditions. Agronomy Journal 45:385-390.

De Santa Olalla, F.M., De Juan Valero, J.M. \& Fabiero Cortes, C. 1994. Growth and production of onion crop (Allium cepa L.) under different irrigation scheduling. European Journal of Agronomy 3:85-92.

DeTar, W.R., Browne, G.T., Phene, C.J. \& Sanden, B.L. 1996. Real-time irrigation scheduling of potatoes with sprinkler and subsurface drip systems. p.812-824. In: C.R. Camp et al. (ed.) Proc. Int. Conf. on Evapotranspiration and Irrigation Scheduling, San Antonio, TX, Am. Soc. Agric. Eng., St. Joseph, MI.

Dinar, A. 1993. Economic factors and opportunities as determinants of water use efficiency in agriculture. Irrigation Science 14:47-52.

Doorenbos, J. \& Pruitt, W.O. 1977. Guidelines for predicting crop water requirements. Rome: FAO. 156p. (Irrigation and Drainage Paper, 24).

Doorenbos, J. \& Kassam, A.H. 1979. Yield response to water. Rome: FAO. 193p. (Irrigation and Drainage Paper, 33).

Ellis, J.E., Kruse, E.G., McSay, A.E., Neale, C.M.U. \& Horn, R.A. 1986. A comparison of five irrigation methods on onions. HortScience 21:1349-1351. 
Farahani, H.J., Izzi, G., Steduto, P. \& Oweis, T.Y. 2009. Parameterization and evaluation of AquaCrop for full and deficit irrigated cotton. Agronomy Journal 101:469-476.

Faria, R.T., Campeche, F.S.M. \& Chibana, E.Y. 2006. Construction and calibration of high precision lysimeters. Revista Brasileira de Engenharia Agrícola e Ambiental 10:237-242.

Feibert, E.G.B., Shock, C.C. \& Saunders, L.D. 1995. A comparison of sprinkler, subsurface drip, and furrow irrigation of onions. P.59-67. In Malheur Experiment Station annual report 1996. Spec. Rep. 947. Oregon State Univ. Agric. Exp. Stn., Corvallis.

Gallardo, M., Jackson, L.E., Schulbach, K., Snyder, R.L., Thompson, R.B. \& Wyland, L.J. 1996. Production and water use in lettuce under variable water supply. Irrigation Science 16:125-137.

García-Vila, M., Fereres, E., Mateos L., Orgaz, F. \& Steduto, P. 2009. Deficit irrigation optimization of cotton with AquaCrop. Agronomy Journal 101:477-487.

Geerts, S., Raes, D., Garcia, M., Miranda, R., Cusicanqui, J.A., Taboada, C., Mendoza, J., Huanca, R., Mamani, A., Condori, O., Mamani, J., Morales, B., Osco, V. \& Steduto, P. 2009. Simulating Yield Response to Water of Quinoa (Chenopodium quinoa Willd.) with FAO-AquaCrop. Agronomy Journal 101:499-508.

Gomide, R.L., Oliveira, C.S.G. \& Faccioli, G.G. Protótipo de um lisímetro de pesagem automático para estudos em casa de vegetação. In: Congresso Brasileiro de Agrometeorologia, 10, Piracicaba, 1997, p.225-227.

Hanson, B.R., Schwankl, L.J., Schulbach, K.F. \& Pettygrove, G.S. 1997. A comparison of furrow, surface drip, and subsurface drip irrigation on lettuce yield and applied water. Agric. Water Manage. 33:139-157.

Heng, L.K., Evett, S.R., Howell, T.A. \& Hsiao, T.C. 2009. Calibration and testing of FAO AquaCrop model for maize in several locations. Agronomy Journal 101:488:-498.

Howell, T.A., Tolk, J.A., Schneider, A.D. \& Evett, S.R. 1998. Evapotranspiration, yield, and water use efficiency of corn hybrids differing in maturity. Agronomy Journal 90:3-9.

Hsiao, T.C., Heng, L.K., Steduto, P., Raes, D. \& Fereres, E. 2009. AquaCrop-Model parameterization and testing for maize. Agronomy Journal 101:448-459.

Kajada, J. \& Tooming, H. 2004. Potato production model based on principle of maximum plant productivity. Agricultural and Forest Meteorology 127:1-16.

Kooman, P.L. \& Haverkort, A.J. 1995. Modelling development and growth of the potato crop influenced by temperature and daylength: LINTUL-POTATO. In: Haverkort, A.J. \& D.K.L. Mac Kerron (eds.) Potato ecology and modeling of crops under conditions limiting growth. Kluwer Academic Publishers, Dordrecht, p.41-60.

Letey, J. 1993. Relationship between salinity and efficient water use. Irrigation Science 14:7584.

Lin, S.S.M., Hubbel, J.N., Samson Isou, S.C.S. \& Splittstoesser, W.E. 1983. Drip irrigation and tomato yield under tropical conditions. Hortscience 18: 460-161.

Marin, F.R. 2000. Evapotranspiração, transpiração e balanço de energia em pomar de limaácida "Tahiti". Dissertação (Mestrado em Irrigação e Drenagem) - Escola Superior de Agricultura "Luiz de Queiroz", Universidade de São Paulo. 73p.

Mendonça, J.C., Souza, E.F., Bernardo, S., Dias, G.P. \& Grippa, S. 2003. Comparação entre métodos de estimativa da evapotranspiração de referência (ETo) na região Norte Fluminense, RJ. Revista de Brasileira de Engenharia Agrícola e Ambiental 7:275-279. 
Miller, J.S. \& Johnson, D.A. 2000. Competitive fitness of Phytophthora infestans isolates under semiarid field conditions. Phytopathology 90:220-227.

Mishra, H.S., Rathore, T.R. \& Tomar, V.S. 1995. Water use efficiency of irrigated wheat in the Tarai Region of India. Irrigation Science 16:75-80.

Neibling, H. \& Brooks, R. 1995. Potato production using subsurface drip irrigation - Water and nitrogen management. p.656-663. In: F.R. Lamm (ed.) Proc. Int. Microirrig. Congr., 5th, Orlando, FL. 2-6 Apr. 1995. Am. Soc. Agric. Eng., St. Joseph, MI.

Nkemdirim, L.C. 1976. Crop development and water loss - A case study over a potato crop. Agricultural and Forest Meteorology 16:371-388.

Pawar, S.J. \& Firake, N.N. 2003. Effect of irrigation levels and micro-irrigation methods on yield of cabbage. Journal of Maharashtra Agricultural University 28:116-117.

Pereira, A.B, Pedras, J.F., Villa Nova, N.A. \& Cury, D.M. 1995a. Water consumption and crop coefficient of potato (Solanum tuberosum L.) during the winter season in municipality of Botucatu-SP. Revista Brasileira de Agrometeorologia 3:59-62.

Pereira, A.B., Villa Nova, N.A., Tuon, R.L. \& Barbieri, V. 1995b. Estimate of the maximum evapotranspiration of potato crop under the edaphoclimatic conditions of Botucatu, SP, Brazil. Revista Brasileira de Agrometeorologia 3:53-58.

Pereira, A.B. \& Villa Nova, N.A. 2008. Potato maximum yield as affected by crop parameters and climatic factors in Brazil. HortScience 43:1611-1614.

Pereira, A.B., Villa Nova, N.A. \& Alfaro, A.T. 2009. Water requirements of citrus and Apple trees affected by leaf area and solar energy. 2009. Revista Brasileira de Fruticultura 31:671-679.

Pereira, A.B., Villa Nova, N.A., Alfaro, A.T. \& Pires, L.F. 2010. Transpiration of irrigated apple trees and citrus from a water potential gradient approach in the leafatmosphere system. Revista Brasileira de Meteorologia 25:xi-xf. [In print].

Pereira, A.R., Angelocci, L.R. \& Sentelhas, P.C. 2002. Agrometeorologia: fundamentos e aplicações. Guaíba: Agropecuária. 478p.

Powelson, M.L., Johnson, K.B. \& Rowe, R.C. 1993. Management of diseases caused by soilborne pathogens. P.149-158. In: R.C. Rowe (ed.) Potato health management. ASP Press, Wooster, OH.

Prieto, M.H., Lopez, J. \& Ballesteros, R. 1999. Influence of irrigation system and strategy on the agronomic and quality parameters of the processing tomato in Extremadura. Acta Hortic. 487:575-579.

Pruitt, W.O, Fereres, E., Martin, P.E., Singh, H., Henderson, D.W., Hagan, R.M., Tarantino, E. \& Chandio, B. 1984. Microclimate, evapotranspiration, and water-use-efficiency for drip- and furrow- irrigated tomatoes. p. 367-394. In Int. Congr. on Irrig. and Drain., 12th, Fort Collins, CO. 28 May-2 June 1984. Vol. 1A. U.S. Committee on Irrig. and Drain., Denver, CO.

Reichardt, K. 1985. Processos de transferência no sistema solo-planta-atmosfera. $4^{\text {a }}$ edição. Campinas, Fundação Cargill. 446p.

Richards, R.A., López-Castañeda, C., Gomez-Macpherson, H. \& Condon. A.G. 1993. Improving the efficiency of water use by plant breeding and molecular biology. Irrigation Science 14:93-104. 
Saeed, I.A.M. \& El-Nadi, A.H. 1997. Irrigation effects on the growth, yield, and water use efficiency of alfalfa. Irrigation Science 17:63-68.

Sammis, T.W. 1980. Comparison of sprinkler, trickle, subsurface and furrow irrigation methods for row crops. Agronomy Journal 72:701-704.

Sammis, T.W., Kratky, B.A. \& Wu, I.P. 1988. Effects of limited irrigation on lettuce and Chinese cabbage yields. Irrigation Science 9:187-198.

Sanchez, C.A. 2000. Response of lettuce to water and nitrogen on sand and the potential for leaching nitrate-N. HortScience 35:73-77.

Sharanappa-Jangandi, Shekar, B.G. \& Sridhara, S. 2001. Water use efficiency and yield of cabbage as influenced by drip and furrow methods of irrigation. Indian Agric. 44:153-155.

Shock, C.C., Hobson, J.H., Seddigh, M., Shock, B.M., Stieber, T.D. \& Saunders, L.D. 1997. Mechanical straw mulching of irrigation furrows: Soil erosion and nutrient losses. Agronomy Journal 89:887-893.

Shock, C.C., Feibert, E.B.G. \& Saunders, L.D. 1998. Potato yield and quality response to deficit irrigation. HortScience 33:655-659.

Shock, C.C. \& Shock, B.M. 1998. Comparative effectiveness of polyacrylamide and straw mulch to control erosion and enhance water infiltration. p. 429-444. In A. Wallace and R.E. Terry (ed.) Handbook of soil conditioners. Marcel Dekker, New York.

Shock, C.C., Jensen, L.B., Hobson, J.H., Seddigh, M., Shock, B.M., Saunders, L.D. \& Stieber, T.D. 1999. Improving onion yield and market grade by mechanical straw application to irrigation furrows. HortTechnology 9:251-253.

Shock, C.C., Feibert, E.B.G. \& Saunders, L.D. 2000. Irrigation criteria for drip-irrigated onions. HortScience 35:63-66.

Silva, F.C., Folegatti, M.V. \& Maggiotto, S.R. 1999. Análise do funcionamento de um lisímetro de pesagem com célula de carga. Revista Brasileira de Agrometeorologia 7:5358.

Srinivas, K., Hegede, D.M. \& Havanagi, G.V. 1989. Plant water relations, canopy temperature, yield and water-use efficiency of water melon (Citrulls lanatus (Thamb.) Matsum et Nakai) under drip and furrow. Journal of Horticultural Science 64:115-124.

Sousa, V.F. de, Coelho, E.F., Fizzone, J.A., Folegatti, M.V., Andrade Júnior, A.S. \& Oliveira, F. das C. 2000. Eficiência do uso da água pelo meloeiro sob diferentes freqüências de irrigação. Revista Brasileira de Engenharia Agrícola e Ambiental 4:183-188.

Steduto, P., Hsiao, T.C., Raes, D. \& Fereres, E. 2009. AquaCrop - The FAO crop model to simulate yield response to water: I. Concepts and principles. Agronomy Journal 101:426-437.

Sutton, B.G. \& Merit, N. 1993. Maintenance of lettuce root zone at field capacity gives best yields with drip. Sci. Hortic. 56:1-11.

Tan, C.S. 1993. Tomato yield-evapotranspiration relationships, seasonal canopy temperature and stomatal conductance as affected by irrigation. Canadian Journal of Plant Science 73:257-264.

Tan, C.S. 1995. Effect of drip and sprinkler irrigation on yield and quality of five tomato cultivars in southwestern Ontario. Can. J. Plant Sci. 75:225-230. 
Tanner, C.B. 1981. Transpiration efficiency of potato. Agronomy Journal 73:257-264.

Todorovic, M., Albrizio, R., Zivotic, L., Saab, M.T.A., Stöckle, C. \& Steduto, P. 2009. Assessment of AquaCrop, CropSyst, and WOFOST models in the simulation of sunflower growth under different water regimes. Agronomy Journal 101:509-521.

Villa Nova, N.A., Santiago, A.V. \& Rezende, F.C. 2001. Energia Solar: Aspectos físicos de captura de biomassa. Departamento de Ciências Exatas: Escola Superior de Agricultura "Luiz de Queiroz", Universidade de São Paulo.

Villa Nova, N.A., Pilau, F.G., Dourado Neto, D. \& Manfron, P.A. 2005. Estimativa da produtividade de cana-de-açúcar irrigada com base na fixação de $\mathrm{CO} 2$, radiação solar e temperatura do ar. Revista Brasileira de Agrometeorologia 13:405-411.

Villa Nova, N.A., Miranda, J.H., Pereira, A.B. \& Silva, K.O. 2006. Estimation of potential evapotranspiration by a simplified Penman method. Engenharia Agrícola 26:713-721.

Villa Nova, N.A., Pereira, A.B. \& Shock, C.C. 2007. Estimation of reference evapotranspiration by an energy balance approach. Biosystems Engineering 96:605615.

Wright, J.L. 1982. New evapotranspiration crop coefficients. Journal of Irrigation and Drainage ASCE 108:57-74.

Wright, J.L. \& Stark, J.C. 1990. Potato. P.859-888. In: B.A. Stewart and D.R. Nielson (ed.) Irrigation of agricultural crops. Agronomy Monograph 30. ASA, CSSA, and SSSA, Madison, WI. 


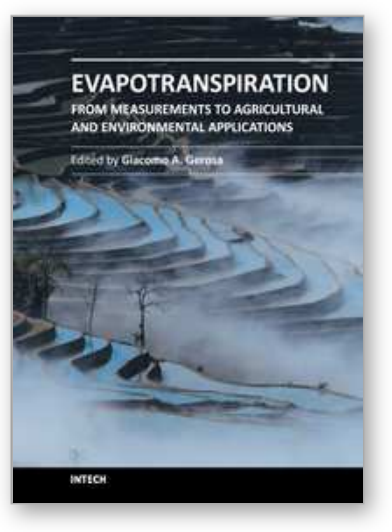

\section{Evapotranspiration - From Measurements to Agricultural and Environmental Applications}

Edited by Dr. Giacomo Gerosa

ISBN 978-953-307-512-9

Hard cover, 410 pages

Publisher InTech

Published online 09, November, 2011

Published in print edition November, 2011

This book represents an overview of the direct measurement techniques of evapotranspiration with related applications to the water use optimization in the agricultural practice and to the ecosystems study. Different measuring techniques at leaf level (porometry), plant-level (sap-flow, lysimetry) and agro-ecosystem level (Surface Renewal, Eddy Covariance, Multi layer BREB), are presented with detailed explanations and examples. For the optimization of the water use in agriculture, detailed measurements on transpiration demands of crops and different cultivars, as well as results of different irrigation schemes and techniques (i.e. subsurface drip) in semi-arid areas for open-field, greenhouse and potted grown plants are presented. Aspects on ET of crops in saline environments, effects of ET on groundwater quality in xeric environments as well as the application of ET to climatic classification are also depicted. The book provides an excellent overview for both, researchers and student,s who intend to address these issues.

\section{How to reference}

In order to correctly reference this scholarly work, feel free to copy and paste the following:

André Pereira and Luiz Pires (2011). Evapotranspiration and Water Management for Crop Production, Evapotranspiration - From Measurements to Agricultural and Environmental Applications, Dr. Giacomo Gerosa (Ed.), ISBN: 978-953-307-512-9, InTech, Available from:

http://www.intechopen.com/books/evapotranspiration-from-measurements-to-agricultural-and-environmentalapplications/evapotranspiration-and-water-management-for-crop-production

\section{INTECH}

open science | open minds

\section{InTech Europe}

University Campus STeP Ri

Slavka Krautzeka 83/A

51000 Rijeka, Croatia

Phone: +385 (51) 770447

Fax: +385 (51) 686166

www.intechopen.com

\section{InTech China}

Unit 405, Office Block, Hotel Equatorial Shanghai

No.65, Yan An Road (West), Shanghai, 200040, China

中国上海市延安西路65号上海国际贵都大饭店办公楼 405 单元

Phone: +86-21-62489820

Fax: $+86-21-62489821$ 
(C) 2011 The Author(s). Licensee IntechOpen. This is an open access article distributed under the terms of the Creative Commons Attribution 3.0 License, which permits unrestricted use, distribution, and reproduction in any medium, provided the original work is properly cited. 